удк 657.1

А. В. Распутина

Байкальский государственный университет, г. Иркутск, Российккая Федерация

\title{
ОСОБЕННОСТИ БЮДЖЕТНОГО УЧЕТА В ГОСУДАРСТВЕННЫХ ВНЕБЮДЖЕТНЫХ ФОНДАХ
}

\begin{abstract}
АНнотАция. Страховые взносы обеспечивают конституционные права граждан России. В статье рассмотрены основные механизмы исчисления и уплаты страховых взносов в государственных внебюджетных фондах. Освещены отличительные особенности начисления и уплаты страховых взносов в Пенсионном фонде России, Фонде социального страхования РФ и фондах обязательного медицинского страхования РФ, которые оказывают влияние на ведение бюджетного учета страховых взносов. Описан порядок исчисления и уплаты страховых взносов в зависимости от их вида и с учетом предельной величины. Изменение структуры кодов бюджетной классификации в 2016 г. при составлении и исполнении бюджетов бюджетной системы Российской Федерации не коснулось составления бюджетной (бухгалтерской) и финансовой отчетности. Основные изменения кодов бюджетной классификации зависят от превышения начислений в пользу работника предельной величины базы для начисления страховых взносов. Средства государственных внебюджетных фондов имеют строго целевое назначение, поэтому бюджетный учет в этих фондах имеет свои особенности. Унифицировать бюджетный учет для всех внебюджетных фондов невозможно, поскольку это разные системы социального страхования. В этой связи бюджетный учет в каждом государственном фонде всегда будет иметь как общие черты, так и отличительные особенности.

кЛЮчЕВЫЕ СЛОВА. Бюджетный учет; коды бюджетной классификации; страховые взносы; тарифы страховых взносов; государственные внебюджетные фонды.

ИНФОРМАЦИЯ О СТАТЬЕ. Дата поступления 8 февраля 2016 г.; дата принятия к печати 26 февраля 2016 г.; дата онлайн-размещения 31 марта 2016 г.

ФИНАНСИРОВАНИЕ. Государственное задание № 2014/52 на выполнение государственных работ в сфере научной деятельности в рамках базовой части проекта № 597 «Разработка методологии финансового обеспечения социально значимых расходов» (номер регистрации в ФГАНУ ЦИТиС 01201458899).
\end{abstract}

\author{
A. V. Rasputina \\ Baikal State University, \\ Irkutsk, Russian Federation
}

\section{FEATURES OF BUDGETARY ACCOUNTING IN GOVERNMENTAL NON-BUDGETARY FUNDS}

\begin{abstract}
Insurance contributions provide the constitutional right of Russia's citizens. The article considers the main mechanisms of calculation and payment of insurance contributions into governmental non-budgetary funds. It highlights peculiar features of calculation and payments of insurance contributions into the Russia's Pension Fund, the RF Social Insurance Fund and funds of obligatory medical insurance which have an effect on maintaining budgetary accounting of insurance contributions. It describes the order of calculating and paying insurance contributions depending on their type and in view of their maximum amount. The change of structure of the budget classification codes in 2016 in preparing and administrating budgets of the Russian Federation budget did not have respect to preparing the budget (accounting) and financial reports. The main changes of budget classification codes depend on exceeding accruals in favor of employees of maximum amount of the insurance contribution calculation base. Recourses of the governmental non-budgetary funds have strict intended purpose, that's why the
\end{abstract}

(C) A. В. Распутина, 2016

\section{Baikal Research Journal}

электронный научный журнал Байкальского государственного университета 
budgetary accounting in these funds have their own features. To unify the budgetary accounting for all non-budgetary funds is impossible as these are different systems of social welfare. In this context, the budgetary accounting in each governmental fund will always have both common and different features.

KEYWORDS. Budgetary accounting; codes of budgetary classification; insurance contributions; insurance contribution tariffs; governmental non-budgetary funds.

ARTICLE INFO. Received February 8, 2016; accepted February 26, 2016; available online March 31, 2016.

FINANCING. Governmental order No. 2014/52 on performance of state work in research activities within the base part of the project No. 597 «Devising the methodology of socially important expenses financial support» (registration No. in FGANU TsITiS 01201458899).

Страховые взносы формально не входят в налоговую систему России, но они играют важнейшую роль в системе обязательного социального страхования в стране. Их уплата обеспечивает конституционное право граждан России на социальное обеспечение по возрасту; социальное обеспечение по болезни, инвалидности, в случае потери кормильца, рождения и воспитания детей и других случаях, предусмотренных законодательством РФ о социальном обеспечении; охрану здоровья и получение бесплатной медицинской помощи.

В настоящее время правовой основой образования государственных внебюджетных фондов являются Конституция РФ и Бюджетный кодекс РФ (БК РФ).

Вопросы обязательного социального страхования и обеспечения рассматривались в трудах Е. В. Агеевой [1], Л. В. Саниной [2; 3], В. И. Самарухи [4], Д. Ю. Федотова [5]. Вопросы бюджетного учета рассматривались в трудах: Т. Г. Арбатской [6], А. П. Киреенко [7], И. А. Слободняка [8-10], Т. В. Сорокиной [11], Т. В. Файберг [12].

Бюджетное законодательство формулирует общие принципы и правовой статус государственных внебюджетных фондов.

В ст. 144 Бюджетного кодекса РФ определен состав внебюджетных фондов. К бюджетам федеральных государственных внебюджетных фондов относятся:

- бюджет Пенсионного фонда России (ПФР);

- бюджет Фонда социального страхования Российской Федерации (ФСС);

- бюджет Федерального фонда обязательного медицинского страхования Российской Федерации (ФФОМС);

- бюджеты территориальных государственных внебюджетных фондов Российской Федерации (ТФОМС).

Необходимо отметить, что каждый из источников формирования доходов бюджетов государственных внебюджетных фондов имеют строго целевое назначение. Доходы их бюджетов формируются только за счет неналоговых доходов и безвозмездных поступлений. Основным источником неналоговых доходов бюджетов федеральных государственных внебюджетных фондов являются страховые взносы, а безвозмездных поступлений - межбюджетные трансферты из федерального бюджета. Основным источником формирования бюджетов территориальных государственных внебюджетных фондов в настоящее время являются межбюджетные трансферты из ФФОМС.

В соответствии с законодательством в Российской Федерации существует четыре вида страховых взносов:

1. Взносы на пенсионное обеспечение. Они делятся на взносы на страховую пенсию и взносы на накопительную пенсию (взносы в ПФР).

2. Взносы на медицинское страхование (взносы в ФФОМС).

3. Взносы на обязательное социальное страхование на случай временной нетрудоспособности и в связи с материнством (взносы в ФСС).

\section{Baikal Research Journal}


4. Взносы на обязательное социальное страхование по страхованию от несчастных случаев на производстве и профзаболеваний (взносы в ФСС).

Исходя из изложенного, отметим, что государственных внебюджетных фондов четыре (ПФР, ФСС, ФФОМС, ТФОМС), видов страховых взносов четыре, а главных администраторов страховых взносов два (ПФР и ФСС). Так, главным администратором страховых взносов на обязательное пенсионное и обязательное медицинское страхование является ПФР, поэтому организации ежеквартально подготавливают отчетность по страховым взносам в два фонда - в ПФР (форма РСВ-1) и ФСС (форма 4-ФСС).

Всем государственным внебюджетным фондам присущи общие черты:

- все внебюджетные фонды контролируются государством;

- отчисления в них производятся работодателями от всех сумм заработной платы работников;

- все внебюджетные фонды по своей экономической природе являются страховыми, т. е. внесенные в них суммы страховых взносов, в принципе, возвратные работодатели, начисляя за своих работников страховые взносы, тем самым страхуют их, и при возникновении страхового случая застрахованное лицо получит страховую выплату.

Виды страховых случаев, которые подлежат оплате из бюджетов государственных внебюджетных фондов, перечислены в табл. 1.

Виды страховых случаев для приобретения права

Таблица 1 на пенсионное, медицинское и социальное обеспечение

\begin{tabular}{|l|l|}
\hline \multicolumn{1}{|c|}{ Внебюджетный фонд } & \multicolumn{1}{|c|}{ Виды страховых случаев } \\
\hline $\begin{array}{l}\text { Пенсионный фонд } \\
\text { России }\end{array}$ & Наступление пенсионного возраста или получение инвалидности \\
\cline { 1 - 2 } & $\begin{array}{l}\text { Момент начала выплаты соответствующей пенсии } \\
\text { Рождение второго или последующих детей (оплата материнского } \\
\text { капита) }\end{array}$ \\
\hline Потеря кормильца \\
\hline $\begin{array}{l}\text { Фонд социального стра- } \\
\text { хования РФ }\end{array}$ & $\begin{array}{l}\text { Момент болезни и оплата листка нетрудоспособности, а также посо- } \\
\text { бия по беременности и родам }\end{array}$ \\
\hline $\begin{array}{l}\text { Федеральный фонд обя- } \\
\text { зательного медицинско- } \\
\text { го страхования РФ }\end{array}$ & $\begin{array}{l}\text { Момент обращения застрахованного лица в медицинское учреждение } \\
\text { за бесплатной медицинской помощью }\end{array}$ \\
\hline
\end{tabular}

Основные механизмы исчисления и уплаты страховых взносов определены Федеральным законом «О страховых взносах в Пенсионный фонд Российской Федерации, Фонд социального страхования Российской Федерации, Федеральный фонд обязательного медицинского страхования» от 24 июля 2009 г. № 212-ФЗ (далее Закон № 212-ФЗ). Данный закон устанавливает: круг плательщиков взносов; облагаемый объект и базу; тарифы страховых взносов; порядок уплаты страховых взносов и контроль за их уплатой; ответственность за нарушение законодательства о страховых взносах и другие вопросы.

Плательщиками страховых взносов являются лица, производящие выплаты и иные вознаграждения физическим лицам (организации; индивидуальные предприниматели, в том числе главы крестьянских (фермерских) хозяйств; физические лица, не являющиеся индивидуальными предпринимателями), а также самозанятое население (индивидуальные предприниматели, адвокаты, нотариусы, занимающиеся частной практикой, арбитражные управляющие не производящие выплаты и иные вознаграждения физическим лицам и уплачивающие страховые взносы за себя).

\section{Baikal Research Journal}

электронный научный журнал Байкальского государственного университета 
Объектом обложения страховыми взносами для организаций и индивидуальных предпринимателей признаются выплаты и иные вознаграждения, начисляемые в пользу физических лиц в рамках трудовых отношений и гражданско-правовых договоров, предметом которых является выполнение работ, оказание услуг (за исключением вознаграждений, выплачиваемых индивидуальным предпринимателям, адвокатам, нотариусам и иным лицам, занимающимся частной практикой); по договорам авторского заказа, в пользу авторов произведений по договорам об отчуждении исключительного права на произведения науки, литературы, искусства, издательским лицензионным договорам, лицензионным договорам о предоставлении права использования произведения науки, литературы, искусства; в пользу физических лиц, подлежащих обязательному социальному страхованию в соответствии с федеральными законами о конкретных видах обязательного социального страхования (ст. 7 Закона № 212-ФЗ).

Объектом обложения страховыми взносами для физических лиц, не признаваемых индивидуальными предпринимателями, признаются выплаты и иные вознаграждения по трудовым договорам и гражданско-правовым договорам, предметом которых является выполнение работ, оказание услуг, выплачиваемые плательщиками страховых взносов в пользу физических лиц (за исключением вознаграждений, выплачиваемых индивидуальным предпринимателям, адвокатам, нотариусам и иным лицам, занимающимся частной практикой); суммы, не подлежащие обложению страховыми взносами, для плательщиков страховых взносов, производящих выплаты и иные вознаграждения физическим лицам, указаны в ст. 9 Закона № 212-ФЗ.

Положения ст. 9 Закона № 212-ФЗ вызывают у плательщиков страховых взносов наибольшее количество вопросов, поскольку они предоставляют возможность уменьшать эти суммы.

Вознаграждения в пользу физических лиц не подлежат обложению страховыми взносами по разным причинам. Некоторые просто не являются объектом обложения, а некоторые были специально освобождены от обложения взносами Законом № 212-Ф3. Однако с такими выплатами следует быть осмотрительнее, поскольку неначисление взносов грозит повышенным вниманием со стороны контролирующих органов и последующей выездной проверкой. Отметим также, что есть выплаты, на которые страховые взносы не начисляются совсем, а есть такие, которые облагаются взносами лишь в некоторые фонды.

Страховыми взносами в ПФР, ФСС и ФФОМС не облагаются:

- выплаты в пользу физических лиц, с которыми нет трудового договора или договора на выполнение работ, оказания услуг. Это, в частности, дети, супруги, родители работников, а также бывшие работники организации (письма Минтруда РФ от 16 сентября 2015 г. № 17-3/В-464, Минздравсоцразвития РФ от 27 мая 2010 г. № 1354-19);

- выплаты по договорам купли-продажи, дарения, аренды, ссуды и займа (ч. 3 ст. 7 Закона № 212-ФЗ; пп. 1, 2 ст. 20.1 Федерального закона «Об обязательном социальном страховании от несчастных случаев на производстве и профессиональных заболеваний» от 24 июля 1998 г. № 125-ФЗ (далее - Закон № 125-ФЗ); письма Минтруда РФ от 22 сентября 2015 г. № 17-3/В-473 и Минздравсоцразвития РФ от 12 марта 2010 г. № 550-19; информация ФСС);

- вознаграждение, выплачиваемое по решению общего собрания участников (акционеров) членам совета директоров (наблюдательного совета), ревизионной комиссии (письма ФСС от 14 апреля 2015 г. № 02-09-11/06-5250 (п. 6) и Минтруда РФ от 20 января 2014 г. № 17-3/В-14);

- дивиденды (письмо ФСС от 17 ноября 2011 г. № 14-03-11/08-13985, информация ФСС);

\section{Baikal Research Journal}


- материальная выгода от экономии на процентах по займам (п. 1 Письма Минтруда от 17.02.2014 № 17-4/В-54);

- выплаты, указанные в ст. 9 Закона № 212-ФЗ и в ст. 20.2 Закона № 125-ФЗ. Это, например, суточные, пособие по больничному, детские пособия (в том числе по беременности и родам и по уходу за ребенком), выходное пособие в сумме, не превышающей трехкратный размер среднего месячного заработка работника (шестикратный размер среднего месячного заработка работника, увольняющегося из организации, расположенной в районах Крайнего Севера или приравненных к ним местностях), некоторые виды материальной помощи.

Тарифы страховых взносов в 2016 г. зависят от видов деятельности организации и от режима налогообложения. Если организация не имеет права на применение пониженных тарифов страховых взносов в 2016 г., то в отношении выплат, не превышающих предельную величину, она должна начислять страховые взносы: в ПФР — по тарифу $22 \%$, ФСС РФ — по тарифу 2,9 \%, ФФОМС — по тарифу 5,1 \% .

Бюджетный учет страховых взносов в государственных внебюджетных фондах имеет свои особенности. Это связано с разным порядком начисления и уплаты страховых взносов в каждом фонде. Отметим отличительные особенности начисления и уплаты страховых взносов в ФСС (табл. 2).

Таблица 2

Отличительные особенности начисления и уплаты страховых взносов в государственные внебюджетные фонды

\begin{tabular}{|c|c|c|}
\hline $\begin{array}{l}\text { Критерий } \\
\text { отличия }\end{array}$ & $\begin{array}{c}\text { Пенсионный фонд России и Феде- } \\
\text { ральный фонд обязательного меди- } \\
\text { цинского страхования РФ }\end{array}$ & Фонд социального страхования РФ \\
\hline $\begin{array}{l}\text { Количество видов } \\
\text { страхования, по } \\
\text { которым уплачива- } \\
\text { ются взносы }\end{array}$ & $\begin{array}{l}\text { Один вид страхования: Пенсион- } \\
\text { ный фонд России - обязательное } \\
\text { пенсионное страхование; Федераль- } \\
\text { ный фонд обязательного медицин- } \\
\text { ского страхования РФ - обязатель- } \\
\text { ное медицинское страхование }\end{array}$ & $\begin{array}{l}\text { Два вида обязательного социального } \\
\text { страхования: на случай временной } \\
\text { нетрудоспособности и в связи с мате- } \\
\text { ринством; от несчастных случаев на } \\
\text { производстве и профессиональных } \\
\text { заболеваний }\end{array}$ \\
\hline \multirow{2}{*}{$\begin{array}{l}\text { Правовое регулиро- } \\
\text { вание }\end{array}$} & \multirow[t]{2}{*}{ Закон № 212-ФЗ } & Вид страхования - Закон № 212-ФЗ \\
\hline & & Вид страхования - Закон № 125-ФЗ \\
\hline $\begin{array}{l}\text { Плательщики стра- } \\
\text { ховых взносов }\end{array}$ & $\begin{array}{l}\text { Лица, осуществляющие и не осу- } \\
\text { ществляющие выплаты в пользу } \\
\text { физических лиц }\end{array}$ & $\begin{array}{l}\text { Только лица, осуществляющие вы- } \\
\text { платы в пользу физических лиц }\end{array}$ \\
\hline \multirow[t]{2}{*}{$\begin{array}{l}\text { Объекты обложе- } \\
\text { ния взносами }\end{array}$} & $\begin{array}{l}\text { Выплаты и вознаграждения, свя- } \\
\text { занные с трудовыми отношениями }\end{array}$ & $\begin{array}{l}\text { По виду страхования - только вы- } \\
\text { платы и вознаграждения, связанные } \\
\text { с трудовыми отношениями }\end{array}$ \\
\hline & $\begin{array}{l}\text { Вознаграждения, выплачиваемые } \\
\text { по гражданско-правовым догово- } \\
\text { рам }\end{array}$ & $\begin{array}{l}\text { По виду страхования включаются } \\
\text { вознаграждения, выплачиваемые по } \\
\text { гражданско-правовым договорам, } \\
\text { если это прописано в договоре }\end{array}$ \\
\hline $\begin{array}{l}\text { Порядок исчисле- } \\
\text { ния и уплаты взно- } \\
\text { са, подлежащего } \\
\text { уплате в фонд }\end{array}$ & $\begin{array}{l}\text { Уплачивается сумма страховых } \\
\text { взносов, исчисленная как произве- } \\
\text { дение облагаемой базы и установ- } \\
\text { ленного тарифа }\end{array}$ & $\begin{array}{l}\text { Уплачивается сумма разницы между } \\
\text { страховыми взносами, исчислен- } \\
\text { ными как произведение облагаемой } \\
\text { базы и установленного тарифа и сум- } \\
\text { мой произведенных страхователем } \\
\text { выплат по соответствующим видам } \\
\text { страхования }\end{array}$ \\
\hline
\end{tabular}

Если рассматривать обязательное медицинское страхование, то можно выделить отличительные особенности исчисления и уплаты страховых взносов работающего и неработающего населения (табл. 3).

\section{Baikal Research Journal}


Расчет базы для начисления страховых взносов в государственных внебюджетных фондах также имеет свои отличия и определяется как сумма выплат и иных вознаграждений, начисленных плательщиками страховых взносов за расчетный период в пользу физических лиц (за исключением сумм, не подлежащих обложению страховыми взносами). Ежегодно с 2010 г. (табл. 4) постановлением Правительства устанавливается предельная величина базы для начисления страховых взносов: 2010 г. 415000 р., 2011 г. - 463000,2012 г. - 512000,2013 г. - 568000,2014 г. - 624000. Страхователи определяют базу для расчета страховых взносов в ПФР, ФФОМС и ФСС нарастающим итогом с начала года отдельно в отношении каждого физического лица.

С 1 января 2015 г. действуют изменения, согласно которым предельная величина базы для расчета страховых взносов определяется по-разному в отношении взносов в ПФР и ФСС РФ, а для взносов в ФФОМС предельный размер базы, при достижении которого взносы не начисляются, отменен (табл. 4).

Отличительные особенности исчисления и уплаты страховых взносов

Таблица 3

на обязательное медииинское страхование

работающего и неработающего населения

\begin{tabular}{|c|c|c|}
\hline Критерий сравнения & Работающее население & Неработающее население \\
\hline $\begin{array}{l}\text { Правовое регулиро- } \\
\text { вание }\end{array}$ & Закон № 212-ФЗ & $\begin{array}{l}\text { Федеральный закон «О порядке } \\
\text { финансирования выплат за счет } \\
\text { средств пенсионных накоплений» } \\
\text { от } 30 \text { ноября } 2011 \text { г. № } 360-\Phi 3\end{array}$ \\
\hline \multirow[t]{2}{*}{$\begin{array}{l}\text { Плательщики взно- } \\
\text { сов }\end{array}$} & $\begin{array}{l}\text { Лица, осуществляющие выплаты в } \\
\text { пользу физических лиц }\end{array}$ & \multirow[t]{2}{*}{$\begin{array}{l}\text { Органы исполнительной власти } \\
\text { субъектов РФ }\end{array}$} \\
\hline & $\begin{array}{l}\text { Лица, не осуществляющие выплаты в } \\
\text { пользу физических лиц }\end{array}$ & \\
\hline Тарифы взносов & $\begin{array}{l}\text { Для первой группы плательщиков - в } \\
\text { процентах к начисленным выплатам } \\
\text { в пользу физических лиц; для второй } \\
\text { группы плательщиков - в процентах к } \\
\text { минимальному размеру оплаты труда }\end{array}$ & $\begin{array}{l}\text { Устанавливаются ежегодно при- } \\
\text { нимаемым постановлением Пра- } \\
\text { вительства РФ в фиксированном } \\
\text { размере на одного неработающе- } \\
\text { го гражданина }\end{array}$ \\
\hline $\begin{array}{l}\text { Порядок и сроки } \\
\text { уплаты взносов }\end{array}$ & $\begin{array}{l}\text { В Федеральном фонде обязательного } \\
\text { медицинского страхования РФ для } \\
\text { первой группы плательщиков ежеме- } \\
\text { сячно до } 15 \text { числа месяца, следующего } \\
\text { за месяцем начисления выплат; для } \\
\text { второй группы плательщиков - один } \\
\text { раз в год до } 31 \text { декабря текущего года }\end{array}$ & $\begin{array}{l}\text { В Федеральном фонде обязатель- } \\
\text { ного медицинского страхования } \\
\text { РФ ежемесячно до } 25 \text { числа } \\
\text { текущего календарного месяца } \\
\text { в размере } 1 / 12 \text { годового объе- } \\
\text { ма бюджетных ассигнований, } \\
\text { предусмотренных на эти цели За- } \\
\text { коном о бюджете субъекта РФ }\end{array}$ \\
\hline $\begin{array}{l}\text { Порядок и сроки } \\
\text { представления рас- } \\
\text { четов }\end{array}$ & $\begin{array}{l}\text { В Пенсионном фонде России для } \\
\text { первой группы плательщиков - до } 15 \\
\text { числа 2-го месяца, следующего за от- } \\
\text { четным периодом; для второй группы } \\
\text { плательщиков - не предусмотрено }\end{array}$ & $\begin{array}{l}\text { В территориальных государ- } \\
\text { ственных внебюджетных фондах } \\
\text { РФ ежеквартально до } 25 \text { числа } \\
\text { месяца, следующего за отчетным } \\
\text { периодом (первый квартал, полу- } \\
\text { годие, девять месяцев }\end{array}$ \\
\hline $\begin{array}{l}\text { Администратор } \\
\text { взносов }\end{array}$ & Пенсионный фонд России & $\begin{array}{l}\text { Территориальные государствен- } \\
\text { ные внебюджетные фонды РФ }\end{array}$ \\
\hline
\end{tabular}

Таблица 4

Предельная величина базы для начисления страховых взносов в 2015-2016 г2., p.

\begin{tabular}{|l|r|r|}
\hline \multicolumn{1}{|c|}{ Страховой фонд } & \multicolumn{1}{|c|}{2015} & \multicolumn{1}{c|}{2016} \\
\hline Пенсионный фонд России & 711000 & 796000 \\
\hline Фонд социального страхования РФ & 670000 & 718000 \\
\hline Федеральный фонд обязательного медицинского страхования РФ & - & - \\
\hline
\end{tabular}

\section{Baikal Research Journal}


При превышении размера предельной величины базы, установленного законодательством РФ, взносы не исчисляются (кроме взносов в ПФР).

Таким образом, при превышении предельной величины базы для начисления страховых взносов начисления производятся в следующем порядке:

- в ПФР Федерации уплачивается 10,0 \% свыше установленной предельной величины базы для начисления страховых взносов на обязательное пенсионное страхование;

- в ФСС на обязательное социальное страхование на случай временной нетрудоспособности и в связи с материнством при превышении лимита базы тариф составляет $0 \%$; на обязательное социальное страхование по страхованию от несчастных случаев на производстве и профзаболеваний предельной величины базы для начисления страховых взносов не применяется;

- в ФФОМС 5,1 \% начисляются на полную сумму выплат сотрудникам независимо от их доходов, т. е. для страховых взносов в ФФОМС предельной величины базы для начисления страховых взносов не применяется.

В настоящее время бухгалтерский учет страховых взносов в учреждениях ведется согласно Инструкции по применению единого плана счетов № 157 н. Для учета страховых взносов применяются счета бухгалтерского учета (табл. 5).

Таблица 5

Счета для бухгалтерского учета страховых взносов в учреждениях

\begin{tabular}{|c|c|c|c|}
\hline \multicolumn{3}{|c|}{ Номер счета } & \multirow[t]{2}{*}{ Расчеты по платежам в бюджеты } \\
\hline 303 & 0 & 0 & \\
\hline 303 & 0 & 2 & $\begin{array}{l}\text { Расчеты по страховым взносам на обязательное социальное страхование на } \\
\text { случай временной нетрудоспособности и в связи с материнством }\end{array}$ \\
\hline 303 & 0 & 6 & $\begin{array}{l}\text { Расчеты по страховым взносам на обязательное социальное страхование от } \\
\text { несчастных случаев на производстве и профессиональных заболеваний }\end{array}$ \\
\hline 303 & 0 & 7 & $\begin{array}{l}\text { Расчеты по страховым взносам на обязательное медицинское страхование в } \\
\text { Федеральный фонд обязательного медицинского страхования РФ }\end{array}$ \\
\hline 303 & 0 & 8 & $\begin{array}{l}\text { Расчеты по страховым взносам на обязательное медицинское страхование в } \\
\text { территориальный фонд обязательного медицинского страхования РФ }\end{array}$ \\
\hline 303 & 0 & 9 & Расчеты по дополнительным страховым взносам на пенсионное страхование \\
\hline 303 & 1 & 0 & $\begin{array}{l}\text { Расчеты по страховым взносам на обязательное пенсионное страхование на } \\
\text { выплату страховой части трудовой пенсии }\end{array}$ \\
\hline 303 & 1 & 1 & $\begin{array}{l}\text { Расчеты по страховым взносам на обязательное пенсионное страхование на } \\
\text { выплату накопительной части трудовой пенсии }\end{array}$ \\
\hline
\end{tabular}

Взносы по дополнительным тарифам уплачиваются с выплат не всем работникам, а только тем, которые вправе уйти досрочно на пенсию, а именно трудящимся на видах работ, указанных в подп. 1-18 п. 1 ст. 27 Федерального закона «О трудовых пенсиях в Российской Федерации» от 17 декабря 2001 г. № 173-ФЗ.

Если в организации не проводилась ни специальная оценка условий труда, ни аттестация рабочих мест, то применяют дополнительные тарифы страховых взносов, которые установлены ч. 1 и 2 ст. 58.3 Закона № 212-ФЗ. Компания, которая провела спецоценку, вправе платить дополнительные взносы в ПФР по тарифам, зависящим от класса условий труда (ч. 1-2.1 ст. 58.3 Закона № 212-ФЗ). Эти взносы направляются на финансирование страховой части трудовой пенсии (ст. 33.2 Федерального закона «Об обязательном пенсионном страховании в Российской Федерации» от 15 декабря 2001 г. № 167-ФЗ).

Инструкции № 157 н и 174 н утверждены в декабре 2010 г. В то время Закон № 212-ФЗ еще не содержал ст. 58.3, в которой установлены взносы по дополнительным тарифам, поэтому на текущий момент по взносам в ПФР предусмотрено три счета:

\section{Baikal Research Journal}

электронный научный журнал Байкальского государственного университета 
- 030309000 «Расчеты по дополнительным страховым взносам на пенсионное страхование»;

- 030310000 «Расчеты по страховым взносам на обязательное пенсионное страхование на выплату страховой части трудовой пенсии»;

- 030311000 «Расчеты по страховым взносам на обязательное пенсионное страхование на выплату накопительной части трудовой пенсии».

Поскольку взносы по дополнительным тарифам уплачиваются на страховую часть пенсии, то счет 030311000 исключается автоматически. Остается выбор между счетом 030309000 и 030310000 . Инструкцией № 174н предусмотрены оба эти счета.

При начислении дополнительных взносов в бюджетных учреждениях используется схема бухгалтерских проводок, приведенная в п. 131 Инструкции № 174н. Из анализа этой нормы можно сделать вывод, что счет 030309000 предназначен для отражения операций по начислению дополнительных страховых взносов на накопительную часть пенсии. Так как взносы, начисляемые по дополнительным тарифам, направляются на финансирование страховой части пенсии. Следовательно, дополнительными страховыми взносами они не являются, поэтому суммы должны отражаться на счете 030310 000. Суммы начисленных взносов (по основному и дополнительным тарифам) дифференцируются на уровне аналитического учета и отчетности.

Государственные внебюджетные фонды относятся к типу казенных учреждений, поэтому обязаны применять коды бюджетной классификации (КБК). С 1 января 2016 г. внесены изменения Минфином России в структуру КБК (Приказ Министерства финансов Российской Федерации «О внесении изменений в указания о порядке применения бюджетной классификации РФ, утвержденные приказом Минфина РФ от 1 июля 2013 г. № 65н» от 8 июня 2015 г. № 90н): он остался 20-значным, но код классификации операций сектора государственного управления (КОСГУ) из его структуры исключен, т. е. изменилась не разрядность кода, а его состав.

Так, в код классификации доходов бюджета вместо кода КОСГУ введена аналитическая группа подвида доходов бюджетов (18-20 разряды).

Из кода классификации расходов также исключен код КОСГУ. Но для того, чтобы код классификации расходов по-прежнему оставался 20-значным, увеличено количество разрядов в целевой статье с 7 до 10 знаков. Теперь ее отражают в 8-17 разрядах. Так, разряды с 18 по 20 обозначают код вида расходов.

В структуре кода классификации источников финансирования дефицита бюджета разряды с 18 по 20 занимает аналитическая группа вида источников финансирования дефицита бюджета.

Изменения, внесенные Приказом Минфина России от 8 июня 2015 г. № 90н, применяются при составлении и исполнении бюджетов бюджетной системы РФ, начиная с бюджетов на 2016 г. (на 2016 г. и плановый период 2017 и 2018 гг.). Вместе с тем КОСГУ продолжает использоваться для ведения бюджетного (бухгалтерского) учета, составления бюджетной (бухгалтерской) и финансовой отчетности (табл. 6).

Главные изменения связаны с тем, что при уплате пенсионных взносов за свое страхование для индивидуальных предпринимателей установлены два разных КБК: один - для доходов, не превышающих 300000 р., а другой - для доходов свыше указанной суммы. Раньше такой градации не было и независимо от суммы доходов перечислять взносы за свое страхование предприниматели должны были на КБК 39210202140061000160.

\section{Baikal Research Journal}


Таблица 6

Коды бюджетной классификации для уплаты страховых взносов в 2016 г.

\begin{tabular}{|l|c|}
\hline \multicolumn{1}{|c|}{ Вид страховых взносов } & \multicolumn{1}{|c|}{$\begin{array}{c}\text { Код бюджетной } \\
\text { классификации }\end{array}$} \\
\hline $\begin{array}{l}\text { Страховые взносы на пенсионное страхование в Пенсионный фонд } \\
\text { России за работников в пределах установленной предельной вели- } \\
\text { чины базы на 2016 г. }\end{array}$ & 39210202010061100160 \\
\hline $\begin{array}{l}\text { Страховые взносы на пенсионное страхование в Пенсионный фонд } \\
\text { России за работников свыше установленной предельной величины } \\
\text { базы на 2016 г. }\end{array}$ & 39210202010061200160 \\
\hline $\begin{array}{l}\text { Страховые взносы в бюджет Федерального фонда обязательного } \\
\text { медицинского страхования РФ за работников }\end{array}$ & 39210202101081011160 \\
\hline $\begin{array}{l}\text { Страховые взносы в Фонд социального страхования РФ на обяза- } \\
\text { тельное социальное страхование на случай временной нетрудоспо- } \\
\text { собности и в связи с материнством за работников }\end{array}$ & 39310202090071000160 \\
\hline $\begin{array}{l}\text { Страховые взносы в Фонд социального страхования РФ от несчаст- } \\
\text { ных случаев на производстве и профессиональных заболеваний за } \\
\text { работников }\end{array}$ & 39310202050071000160 \\
\hline $\begin{array}{l}\text { Страховые взносы в Пенсионный фонд России по дополнительно- } \\
\text { му тарифу за застрахованных лиц, занятых на соответствующих } \\
\text { видах работ, по списку 1 }\end{array}$ & 39210202131061000160 \\
\hline $\begin{array}{l}\text { Страховые взносы в Пенсионный фонд России по дополнительно- } \\
\text { му тарифу за застрахованных лиц, занятых на соответствующих } \\
\text { видах работ, по списку } 2\end{array}$ & 39210202132061000160 \\
\hline
\end{tabular}

Введенное в 2016 г. новшество касается выплат в пользу сотрудников. Вместо одного кода, действовавшего ранее, появились два других, которые зависят от того, превысили ли начисления в пользу работника предельную величину базы для начисления пенсионных взносов. Если превышения нет, то указывают КБК 39210202010061100 160, в обратном случае в платежном поручении указывают код 39210202010061200 160. Если же индивидуальные предприниматели относятся к льготной категории плательщиков взносов и применяет пониженные тарифы на основании ст. 58 и 58.1 Закона № 212-ФЗ, то с суммы превышения предельной базы взносы он не уплачивает, поэтому второй КБК ему не потребуется. В бюджет ФСС взносы КБК для уплаты страховых взносов на 2016 г. остались прежними, изменения коснулись только кодов по уплате пеней по этим взносам.

Средства государственных внебюджетных фондов имеют строго целевое назначение, поэтому бюджетный учет в этих фондах имеет свои особенности. Унифицировать бюджетный учет для всех внебюджетных фондов невозможно, поскольку это разные системы социального страхования. В этой связи бюджетный учет в каждом государственном фонде всегда будет иметь как общие черты, так и отличительные особенности.

\section{Список использованной литературы}

1. Агеева Е. В. Изменение роли пенсионных накоплений в системе обязательного пенсионного страхования / Е. В. Агеева // Известия Иркутской государственной экономической академии. - 2015. - Т. 25, № 3. - C. 495-502. - DOI : 10.17150/19933541.2015.25(3).495-502.

2. Санина Л. В. Влияние пенсионного обеспечения на формирование уровня и качества жизни населения [Электронный ресурс] / Л. В. Санина // Известия Иркутской государственной экономической академии (Байкальский государственный университет экономики и права). - 2013. - № 5. - Режим доступа: http://eizvestia.isea.ru/reader/article.aspx?id=18615.

3. Санина Л. В. Направления модернизации предоставления услуг ПФР на территории Иркутской области / М. В. Вихорева, Л. В. Санина / Пенсионная реформа: проблемы реали-

\section{Baikal Research Journal}

электронный научный журнал Байкальского государственного университета 
зации и пути их преодоления / под ред. Д. Ю. Федотова. - Иркутск : Изд-во БГУЭП, 2013. C. 27-36.

4. Самаруха В. И. Современные тенденции развития обязательного медицинского страхования / В. И. Самаруха / Известия Иркутской государственной экономической академии. 2011. — № 2 (76). - С. 41-44.

5. Пенсионная система России: ключевые проблемы и направления реформирования / Т. В. Файберг, Е. О. Баглаев, С. С. Быков [и др.] ; под ред. Д. Ю. Федотова. - Иркутск : Издво БГУЭП, 2013. - 146 с.

6. Арбатская Т. Г. Об особенностях начисления доходов по субсидиям на выполнение государственного (муниципального) задания / Т. Г. Арбатская // Бухгалтерский учет в бюджетных и некоммерческих организациях. - 2015. — № 1 (361). — С. 2-9.

7. Киреенко А. П. Возможности структурных изменений в муниципальном секторе / А. П. Киреенко, Т. В. Сорокина // Известия Иркутской государственной экономической академии. - 2012. - № 5. - С. 19-23.

8. Слободняк И. А. Проблемы автоматизации бухгалтерского учета / И. А. Слободняк, И. В. Пискунов // Бухгалтерский учет в бюджетных и некоммерческих организациях. 2014. - № 7. - С. 29-34.

9. Слободняк И. А. Методические особенности оценки эффективности деятельности учреждений по отдельным направлениям / И. А. Слободняк, А. В. Баенхаева. - Иркутск : Изд-во Байкал. гос. ун-та, 2016. - 222 с.

10. Слободняк И. А. Принципы оценки эффективности деятельности учреждения / И. А. Слободняк // Бухгалтерский учет в бюджетных и некоммерческих организациях. 2014. - № 16. - C. 20-28.

11. Сорокина Т. В. Актуальные проблемы финансирования, учета и контроля в системе обязательного медицинского страхования / Т. В. Сорокина, А. В. Распутина, А. А. Арстамбек // Известия Иркутской государственной экономической академии (Байкальский государственный университет экономики и права). — 2015. — Т. 6, № 3. — DOI : 10.17150/20720904.2015.6(3).3.

12. Файберг Т. В. Проблемы и перспективы налоговых доходов местных бюджетов в РФ / Т. В. Файберг // Налоги и финансовое право. — 2015. — № 10. - С. 141-148.

\section{References}

1. Ageyeva E. V. Changing the role of pension savings in the compulsory pension insurance system. Izvestiya Irkutskoy gosudarstvennoy ekonomicheskoy akademii $=$ Bulletin of Irkutsk State Economics Academy, 2015, vol. 25, no. 3, pp. 495-502. DOI: 10.17150/19933541.2015.25(3).495-502. (In Russian).

2. Sanina L. V. Impact of pension fund scheme on life standards and quality. Izvestiya Irkutskoy gosudarstvennoy ekonomicheskoy akademii (Baykalskiy gosudarstvennyy universitet ekonomiki i prava) = Bulletin of Irkutsk State Economics Academy (Baikal State University of Economics and Law), 2013, no. 5. Available at: http://eizvestia.isea.ru/reader/article.aspx?id=18615. (In Russian).

3. Sanina L. V., Vikhoreva M. V. Modernization directions in offering services of the Russian Pension Fund on the territory of Irkutsk Oblast. In Fedotov D. Yu. (ed.). Pensionnaya reforma: problemy realizatsii $i$ puti ikh preodoleniya [Pension reform: problems of implementation and ways of their overcoming]. Irkutsk, Baikal State University of Economics and Law Publ., 2013, pp. 27-36. (In Russian).

4. Samarukha V. I. Modern trends of obligatory medical insurance development. Izvestiya Irkutskoy gosudarstvennoy ekonomicheskoy akademii = Bulletin of Irkutsk State Economics Academy, 2011, no. 2 (76), pp. 41-44. (In Russian).

5. Faiberg T. V., Baglayev E. O., Bykov S. S. et. al.; Fedotov D. Yu. (ed.). Pensionnaya sistema Rossii: klyuchevye problemy i napravleniya reformirovaniya [The Russian pension system: key issues and directions for reforming]. Irkutsk, Baikal State University of Economics and Law Publ., 2013. 146 p.

6. Arbatskaya T. G. On features of revenue accounting in terms of subsidies for implementing governmental (municipal) assignments. Bukhgalterskii uchet $v$ byudzhetnykh i nekommercheskikh organizatsiyakh = Book Keeping in Budgetary and Non-Commercial Organizations, 2015, no. 1 (361), pp. 2-9. (In Russian).

\section{Baikal Research Journal}


7. Kireyenko A. P., Sorokina T. V. Possibilities of structural changes in municipalsector. Izvestiya Irkutskoy gosudarstvennoy ekonomicheskoy akademii = Bulletin of Irkutsk State Economics Academy, 2012, no. 5 (85), pp. 19-23. (In Russian).

8. Slobodnyak I. A., Piskunov I. V. Problems of automation in accounting. Bukhgalterskii uchet $v$ byudzhetnykh $i$ nekommercheskikh organizatsiyakh $=$ Book Keeping in Budgetary and Non-Commercial Organizations, 2014, no. 7, pp. 29-34. (In Russian).

9. Slobodnyak I. A., Bayenkhayeva A. V. Metodicheskie osobennosti otsenki effektivnosti deyatel'nosti uchrezhdenii po otdel'nym napravleniyam [Methodical features of assessing efficiency of establishments' performance in different directions]. Irkutsk, Baikal State University Publ., 2016. 222 p.

10. Slobodnyak I. A. Principles of assessing efficiency of establishments' performance. Bukhgalterskii uchet $v$ byudzhetnykh i nekommercheskikh organizatsiyakh = Book Keeping in Budgetary and Non-Commercial Organizations, 2014, no. 16, pp. 20-28. (In Russian).

11. Sorokina T. V., Rasputina A. V., Arstambek A. A. Topical issues of financing, accounting and control in the system of compulsory medical insurance. Izvestiya Irkutskoy gosudarstvennoy ekonomicheskoy akademii (Baykalskiy gosudarstvennyy universitet ekonomiki i prava) $=$ Bulletin of Irkutsk State Economics Academy (Baikal State University of Economics and Law), 2015, vol. 6, no. 3. DOI: 10.17150/2072-0904.2015.6(3).3. (In Russian).

12. Faiberg T. V. Problems and prospects of tax revenue of local budgets of the Russian Federation. Nalogi $i$ finansovoe pravo = Taxes and Financial Law, 2015, no. 10, pp. 141-148. (In Russian).

\section{Информация об авторе}

Распутина Алла Владимировна - кандидат экономических наук, доцент, кафедра бухгалтерского учета, аудита и статистики, Байкальский государственный университет, 664003, г. Иркутск, ул. Ленина, 11, e-mail: rasp77@mail.ru.

\section{Author}

Alla V. Rasputina - PhD in Economics, Associate Professor, Chair of Accounting Audit, and Statistics, Baikal State University, 11 Lenin St., 664003, Irkutsk, Russian Federation; e-mail: rasp77@mail.ru.

\section{Библиографическое описание статьи}

Распутина А. В. Особенности бюджетного учета в государственных внебюджетных фондах / А. В. Распутина / Baikal Research Journal. — 2016. — T. 7, № 2. — DOI : 10.17150/24116262.2016.7(2).3.

\section{Reference to article}

Rasputina A. V. Features of budgetary accounting in governmental non-budgetary funds. Baikal Research Journal, 2016, vol. 7, no. 2. DOI: 10.17150/2411-6262.2016.7(2).3. (In Russian).

\section{Baikal Research Journal}

